Rev. High Pressure Sci. Technol., Vol. 7 (1998) 1031 1033

\title{
High-Pressure and -Temperature Synthesis and its XPS Study of $\mathrm{La}_{1-\mathrm{x}} \mathrm{Na}_{\mathrm{x}} \mathrm{TiO}_{3}$
}

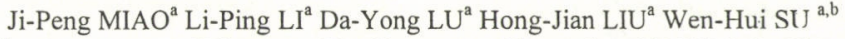 \\ a Department of Physics, Jilin University, Changchun 130023,P.R.China \\ b. International Center for Materials Physics, Academia Sincia ,Shenyang 110015, P.R.China
}

Perovskite oxides of $\mathrm{La}_{1-\mathrm{x}} \mathrm{Na}_{\mathrm{x}} \mathrm{TiO}_{3}(\mathrm{x}=0.05,0.1-0.5)$ were synthesized under high-pressure and -temperature. XRD analysis showed that sample is cubic for $\mathrm{x}=0.05$ and pseudo-cubic for $0.1 \leq \mathrm{x} \leq 0.5$. Cell volumes of samples with $0.1 \leq \mathrm{x} \leq 0.5$ decrease as $\mathrm{x}$ increase, and the cell volume for $\mathrm{x}=0.05$ is less than that for $\mathrm{x}=0.1$. This implies that the deficiency of cation may exist in the samples. XPS and EPR measurements indicated that Ti ions were mixed valence of +3 and +4 and vacancy of A-site ions existed in samples. The valence state of Ti ions can be altered by high-pressure and -temperature.

[high-pressure and -temperature synthesis, phase transition, XPS, EPR, mixed valence]

\section{Introduction}

Perovskite oxide of $\mathrm{RTiO}_{3}$ ( $\mathrm{R}=$ rare earth) has been one of the subjects of recent studies[1-5]. The $\mathrm{RTiO}_{3}$ compounds can be viewed as an distorted perovskite with orthorhombic structure ( $\mathrm{GdFeO}_{3}$-type) where $\mathrm{TiO}_{6}$ octahedron tilts alternatingly. A fairly stoichiometric compound of $\mathrm{LaTiO}_{3}$ system is a Mott insulator and shows an insulating behavior accompanying the antiferro-magnetically spin-ordered phase below $140 \mathrm{~K}[4,6,7]$. Many studies about substitution by divalent ions $\left(\mathrm{Ba}^{2+}, \mathrm{Sr}^{2+}\right.$ and $\mathrm{Ca}^{2+}$ ) for $\mathrm{La}^{3+}$ have been reported[8-13]. But the reports about substitution by monovalent alkali metal ions are less frequent than by divalent alkali-earth metal ions. Some studies about the paraelectricity, thermostability and ion conductivity of $\mathrm{La}_{0.5} \mathrm{Na}_{0.5} \mathrm{TiO}_{3}$ system have been carried out[14-17]. In Ref.[18], polycrystalline materials of $\mathrm{La}_{1-\mathrm{x}} \mathrm{Na}_{\mathrm{x}} \mathrm{TiO}_{3}(0 \leq \mathrm{x} \leq$ 0.4 ) were prepared by solid-state reaction under an $\mathrm{Ar}$ atmosphere by mixing stoichiometric amounts of $\mathrm{LaTiO}_{3}$ and $\mathrm{La}_{0.5} \mathrm{Na}_{0.5} \mathrm{TiO}_{3}$. $\mathrm{LaTiO}_{3}$ was prepared by heating a stoichiometric mixture of $\mathrm{La}_{2} \mathrm{O}_{3}, \mathrm{Ti}_{2} \mathrm{O}_{3}$ and $\mathrm{TiO}$ in an $\mathrm{Ar}$ atmosphere. $\mathrm{La}_{0.5} \mathrm{Na}_{0.5} \mathrm{TiO}_{3}$ was prepared by heating a mixture of $\mathrm{La}_{2} \mathrm{O}_{3}, \mathrm{TiO}_{2}$ and $\mathrm{Na}_{2} \mathrm{CO}_{3}$. The products with $\mathrm{x} \geq 0.1$ showed semiconductor to metal transitions as temperature decreased, and striking decreases of resistivity around $25 \mathrm{~K}$ were observed. Because $\mathrm{Ti}^{4+}$ ions are stablest, at ambient pressure the compounds $\mathrm{La}_{1-\mathrm{x}} \mathrm{M}_{\mathrm{x}} \mathrm{TiO}_{3}\left(\mathrm{M}=\mathrm{Ba}^{2+}, \mathrm{Sr}^{2+}, \mathrm{Ca}^{2+}, \mathrm{k}^{+}\right.$and $\left.\mathrm{Na}^{+}\right)$ using in previous work were synthesized under $\mathrm{Ar}$ atmosphere using $\mathrm{TiO}_{2}, \mathrm{Ti}_{2} \mathrm{O}_{3}$ and $\mathrm{TiO}$ as starting materials or under reducing atmosphere using $\mathrm{TiO}_{2}$. Different preparing methods by using different starting materials may give different results. From our experience, the valence state of ions may be altered by high-pressure and -temperature. So we synthesized the samples $\mathrm{La}_{1-x} \mathrm{Na}_{x} \mathrm{TiO}_{3}$ under $2.8 \sim 4.0 \mathrm{GPa}$ and at $930 \sim 1090^{\circ} \mathrm{C}$ by using $\mathrm{La}_{2} \mathrm{O}_{3}, \mathrm{NaHCO}_{3}$ and $\mathrm{TiO}_{2}$ as starting materials. The structure of samples and valence states of cations were determined by XRD, XPS and EPR respectively.

\section{Experimental}

$\mathrm{La}_{1-\mathrm{x}} \mathrm{Na}_{\mathbf{x}} \mathrm{TiO}_{3}$ oxides were prepared by mixing stoichiometric amounts of $\mathrm{La}_{2} \mathrm{O}_{3}, \mathrm{NaHCO}_{3}$ and $\mathrm{TiO}_{2}$. These starting compounds were thoroughly ground and then put into high pressure chamber (see Fig.1). The pressure was increased to the expected value $(2.8 \sim 4.0 \mathrm{GPa})$. The temperature was then increased gradually to the expected value $\left(930 \sim 1090^{\circ} \mathrm{C}\right)$. After being kept at high-pressure and -temperature for the expected value $(30 \sim 50 \mathrm{~min})$, the specimens were quenched to room temperature under high pressure, and finally the pressure was released.

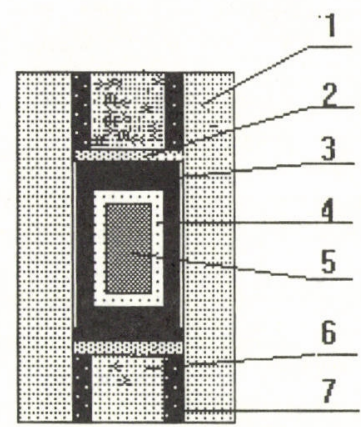

Fig.1. Pressuring chamber

1.Pyrophyllite 2. Molybdenum metal pellet 3. Graphite heater 4 . h-BN tube 5. Sample 6. Pyrophyllite 7. steel cylinder

Powder X-ray diffraction data were collected at $25^{\circ} \mathrm{C}$ on a Rigaku $12 \mathrm{~kW}$ copper rotating anode $\mathrm{X}$-ray diffractometer with a graphite monochromator attachment. The XPS for powder sample were measured on an ESCALAB MKII X-ray photoelectron spectrometer with $\mathrm{MgK}_{\alpha}$ radiation and the base pressure was $10^{-7} \mathrm{~Pa}$. C1s $=284.6$ was used to correct the charge effect. The EPR for powder sample were measured on a BLUKER ER200D EPR spectrometer at room temperature with Microwave Frequency $=9.77 \mathrm{GHz}$, Microwave Power $=6.5 \mathrm{~mW}$, Modulator Frequency $=100 \mathrm{KHz}$ and Field Modulation intensity $=0.32 \mathrm{mT}$.

\section{Results and discussion}

The XRD patterns of the samples are shown in Fig . 2. The samples with $x=0.05$ and 0.1 are single phase. The analysis 
indicated that the sample with $\mathrm{x}=0.05$ is identified to cubic structure and that with $0.1 \leq \mathrm{x} \leq 0.5$ to pseudo-cubic, although small amount of an impurity phase $\left(\mathrm{TiO}_{2}\right)$ were detected. According the nominal ratio of $\mathrm{La}_{1-\mathrm{x}} \mathrm{Na}_{\mathrm{x}} \mathrm{TiO}_{3}$, the ratio of cation number is $(\mathrm{La}, \mathrm{Na}) / \mathrm{Ti}=1$. When the amount of $\mathrm{Na}$ ions deflect the ratio, the amount of $\mathrm{B}$-cation ( $\mathrm{Ti}$ ion ) may decrease in order to maintain the perovskite structure. The appearance of $\mathrm{TiO}_{2}$ may be related with the loss of $\mathrm{Na}$ ions during synthesis. Thus, as the value of $\mathrm{x}$ increased, their crystal structures varied from cubic to pseudo-cubic. This variation is attributed to different ratio of $\mathrm{La} / \mathrm{Na}$ and $\mathrm{Ti}^{4+} / \mathrm{Ti}^{3+}$. In Ref.[18], the sample is pseudo-cubic for $x=0.1$ and cubic for $0.2 \leq \mathrm{x} \leq 0.4$. Different preparing methods and starting materials give different results. Some studies about sample with $x=0.5$ were reported, but gave different lattice structures. The sample is cubic in Ref.[14], tetragonal in Ref.[15] and pseudo-cubic in Ref.[16,17], but our results is the same as Ref.[16,17]. In our sample with $x=0.5$, weak diffraction peak such as $(11 / 31 / 3)\left(\right.$ at about $\left.38^{\circ}\right)$ arising from the superlattice with double period of the primitive cell was observed. The distribution of $\mathrm{La}^{3+}$ and $\mathrm{Na}^{+}$is disordered. The superlattice diffraction peaks may be due to the tilt of oxygen octahedron. The lattice parameters were calculated for samples with $\mathrm{x} \leq$ 0.5 . The relationship between cell volume and $x$ is shown in Fig.3. The cell volume of pseudo-cubic phase decreased as $x$ increases, but that for $\mathrm{x}=0.05$ sample is smaller than that for $\mathrm{x}=0.1$. From the formula of $\mathrm{La}_{0.5} \mathrm{Na}_{0.5} \mathrm{TiO}_{3}, \mathrm{La}^{3+}$ and $\mathrm{Na}^{+}$in $\mathrm{A}$ site are both $50 \%$ respectively, so the valence of $\mathrm{Ti}$ ions is +4 . In order to maintain the electrical neutrality, there must be $\mathrm{Ti}^{3+}$ ions or vacancy of A-site ions for samples with $0.05 \leq \mathrm{x} \leq$ 0.4 . From the results of XPS and EPR, both $\mathrm{Ti}^{3+}$ ions and vacancy of A-site ions exist in samples with $0.1 \leq x \leq 0.5$. The decrease of cell volume with $x$ suggests that the effect of $B$ site substitution $\left(\mathrm{Ti}^{3+}(0.067 \mathrm{~nm})\right.$ to $\left.\mathrm{Ti}^{4+}(0.0605 \mathrm{~nm})\right)$ is dominant over that of A-site substitution $\left(\mathrm{La}^{3+}(0.136 \mathrm{~nm})\right.$ to $\left.\mathrm{Na}^{+}(0.139 \mathrm{~nm})\right)$. As only $\mathrm{Ti}^{3+}$ ions exist in sample with $\mathrm{x}=0.05$ and no vacancy of A-site ions exist, as detected by EPR, its cell volume shows smaller value.

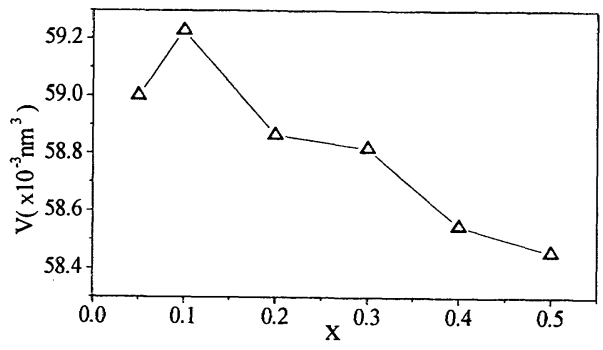

Fig.3. The change of cell volumes vers dopant $\mathrm{x}$.

The binding energies of core levels are given in Table 1. It can be seen that the binding energies of $\mathrm{La}_{3 / 2}$ are between $835.0 \mathrm{eV}$ and $835.6 \mathrm{eV}$, which infers that $\mathrm{La}$ ions are in trivalent state.

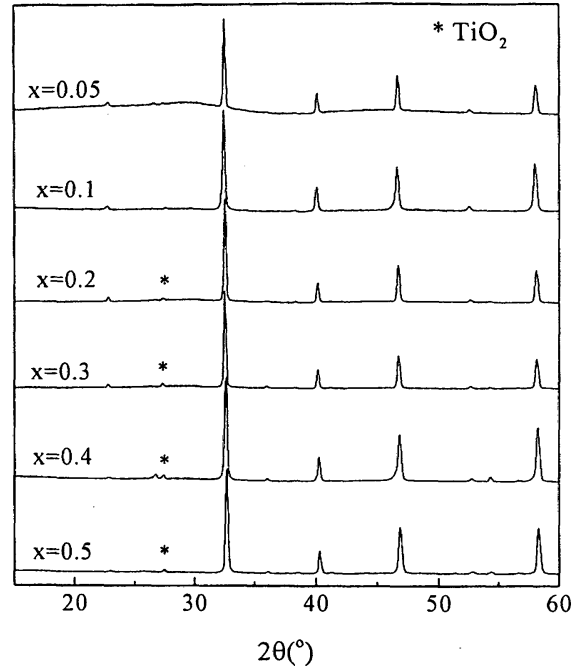

Fig.2. XRD patterns of $\mathrm{La}_{1-\mathrm{x}} \mathrm{Na}_{\mathrm{x}} \mathrm{TiO}_{3}$ samples.

Table 1. Binding energies of core level for $\mathrm{La}_{1-\mathrm{x}} \mathrm{Na}_{\mathbf{x}} \mathrm{TiO}_{3}$

\begin{tabular}{ccccc}
\hline $\mathrm{x}$ & $\mathrm{O}_{1 \mathrm{~S}}$ & ${\mathrm{La} 3 \mathrm{~d}_{5 / 2}}$ & $\mathrm{Na}_{1 \mathrm{~S}}$ & $\mathrm{Ti}_{2} \mathrm{p}_{3 / 2}$ \\
\hline 0.05 & 530.3 & 835.6 & 1071.2 & 458.7 \\
0.1 & 530.5 & 835.0 & 1071.5 & 458.1 \\
0.2 & 530.9 & 835.1 & 1071.6 & 458.5 \\
0.3 & 531.3 & 835.0 & 1071.6 & 458.4 \\
0.4 & 531.8 & 835.3 & 1071.5 & 458.2 \\
0.5 & 532.0 & 835.6 & 1072.2 & 458.4 \\
\hline
\end{tabular}

The half height widths of Ti2 $\mathrm{p}_{3 / 2}$ of samples are given in Fig.4. The Ti2p spectra for $\mathrm{Ti}_{4} \mathrm{O}_{7}$ and $\mathrm{Ti}_{3} \mathrm{O}_{5}$ were reported[19]. It is found that there is a shoulder at low binding energy (BE) apart from main peak about $1 \mathrm{eV}$, which is thought $\mathrm{Ti}^{3+} 2 \mathrm{p}_{3 / 2}$. As the $\mathrm{Ti}^{3+}$ ions are easily oxidized to $\mathrm{Ti}^{4+}$ ions in air, the $\mathrm{Ti}^{3+} 2 \mathrm{p}_{3 / 2}$ peaks for our samples are not easily detected. However, the half height width of $2 p_{3 / 2}$ photoelectron peak of $\mathrm{Ti}$ ions in mixed valence is wider than that of single $\mathrm{Ti}^{4+}$ ions owing to the different binding energy (BE) of $\mathrm{Ti}^{3+} 2 \mathrm{p}_{3 / 2}$ and $\mathrm{Ti}^{4+} 2 \mathrm{p}_{3 / 2}$. The measurements for core level of Ti2p show that the half height widths of Ti2 $p_{3 / 2}$ for the samples with $0.05 \leq \mathrm{x} \leq 0.4$ are larger than that of $\mathrm{TiO}_{2}$ $(1.94 \mathrm{eV})$ and for $\mathrm{x}=0.5$ is almost same. This suggests that $\mathrm{Ti}$ ions may be in mixed valence for $\mathrm{x} \neq 0.5$.

In order to investigate the valence state of $\mathrm{Ti}$ ions exactly, the EPR of samples was detected, as shown in Fig.5. Two strong signals for samples with $0.1 \leq \mathrm{x} \leq 0.4$ at room temperature are observed. One is narrow, and the other is broad. Their g-values are 2.003 and 1.943 respectively. But only one broad signal with $\mathrm{g}=1.943$ is observed for sample with $\mathrm{x}=0.05$. The studies about $\mathrm{BaTiO}_{3}$ and donored $\mathrm{BaTiO}_{3}$ showed two EPR signals with $\mathrm{g}=2.00$ and 1.96 respectively[20,21]. The signal with $g=2.00$ is resulted from 


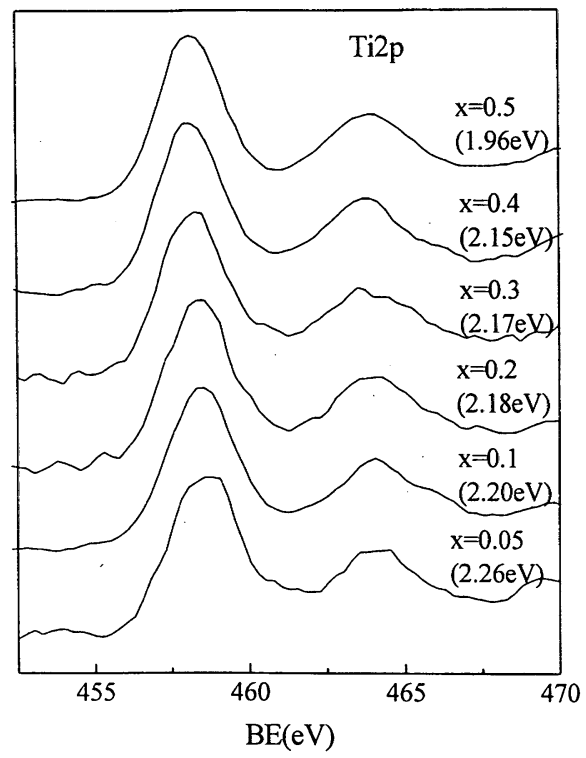

Fig.4. Core level spectra of Ti2p.

(the data in parenthesis are half height width of Ti2 $\mathrm{p}_{3 / 2}$ )

vacancy of barium, and the signal with $g=1.96$ is related with $\mathrm{Ti}^{3+}$ ions. So for our samples, the signal with $\mathrm{g}=2.003$ is related with the vacancy of A-cation and the signal with $\mathrm{g}=1.943$ is related with $\mathrm{Ti}^{3+}$ ions. The existence of $\mathrm{Ti}^{3+}$ ions shows that the valence state of $\mathrm{Ti}^{4+}$ ions can be altered by high-pressure and -temperature.

\section{References}

[1] C. W. Turner, M. F. Collins and J. E. Greedan, J. Magn. Magn. Mater. 23, 265(1981).

[2] D. A. MacLean, K. Seto and J. E. Greedan, J. Solid State Chem., 40, 241(1981).

[3] D. A. MacLean and J. E. Greedan, Inorg. Chem. 20, 1025(1981).

[4] F. Lichtenberg, D. Widmer, J. G. Bednorz, T. Williams and A. Reller, Z. Phys. B 82, 211(1991).

[5] D. A. MacLean, H. K. Greedan and J. E. Greedan, J. Solid State Chem., 30, 35(1979).

[6] Y. Tokura, T. Taguchi, Y. Okada, Y. Fujifhima, T. Arima, K. Kumagai and Y. Iye, Phys. Rev. Lett. 70, 2126(1993).

[7] Y. Okada, T. Arima and Y. Tokura, Phys. Rev. B 48(13), 9677(1993).

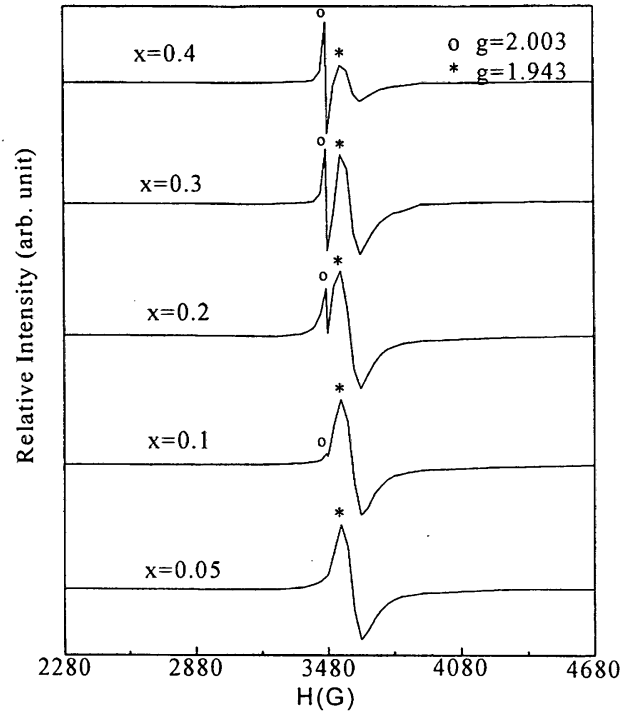

Fig.5. EPR patterns of $\mathrm{La}_{1-\mathrm{x}} \mathrm{Na}_{\mathrm{x}} \mathrm{TiO}_{3}$ samples.

[8] Y. Maeno, S. Awaji, H. Matsumoto and T. Fujita, Physica $B, 165 \& 166,1185$ (1990).

[9] C. Eylem, H. L. Ju, B. W. Eichhorn and R. L. Greene, J. Solid State Chem., 114, 164 (1995).

[10] S. A. Howard, J. K. Yau and H. U. Anderson, J. Appl. Phys., 65(4), 1492(1989).

[11] Y.Taguchi, Y. Tokura, T. Arima and F. Inaba, Phys. Rev. B 48(1), 511(1993).

[12] Y.Taguchi, Y. Okada, Y. Fujishima and Y. Tokura, Phys. Rev. B 48(10), 7636(1993).

[13] T. Katsufuji and Y. Tokura, Phys. Rev. B 49(6), 4372(1994).

[14] N. A. Kirsanov and G. V. Bazuev, Z. Neorg. Khim., 33, 1004(1988).

[15] L. L. Kochergina, Z. Neorg. Khim., 29, 879(1984).

[16] H. Takahashi, J. Appl. Phys. Part1, 30, 2339(1991).

[17] Y. Inaguma, J. H. Sohn, I. S. Kim, M. Itoh and T. Nakamura, J. Phys. Soc. Jpn., 61, 3831(1992).

[18] H. Yamamoto, T. Tahara, Y. Sugahara, K. Kuroda and C. Kato, Phase Transitions, 41, 137 141 (1993).

[19] C. N. R. Rao and D. D. Saarma, J. Solid State Chem., 45, 14(1982).

[20] T. R. N. Kutty, P. Murugaraj and N. S. Gajbhiye, Mater. Res. Bull. 20, 565(1985).

[21] T. R. N. Kutty, P. Murugaraj and N. S. Gajbhiye, Mater. Lett. 2(5A), 396(1984). 